\title{
Les particules élémentaires
}

Le saviez-vous? Le Web a été inventé dans l'Ain et le département abrite l'un des fleurons mondiaux de la recherche nucléaire. Les scientifiques seront présents au forum multimédia pour expliquer le big bang et l'évolution de la tarte au sucre. L'image du savant dans sa tour d'ivoire devrait s'en trouver modifiée

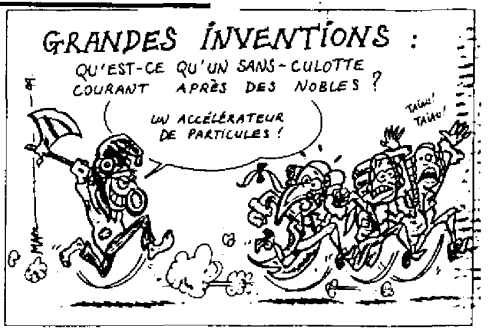

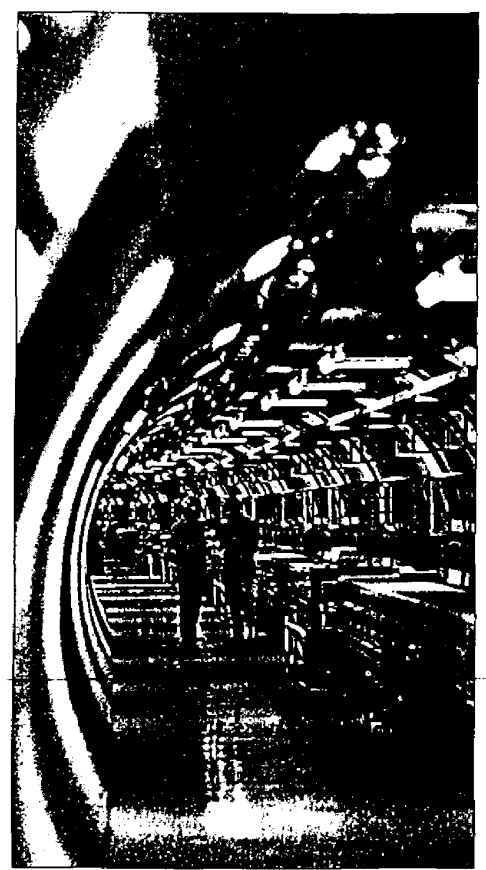

A l'intérleur de l'accélérateur de particules.

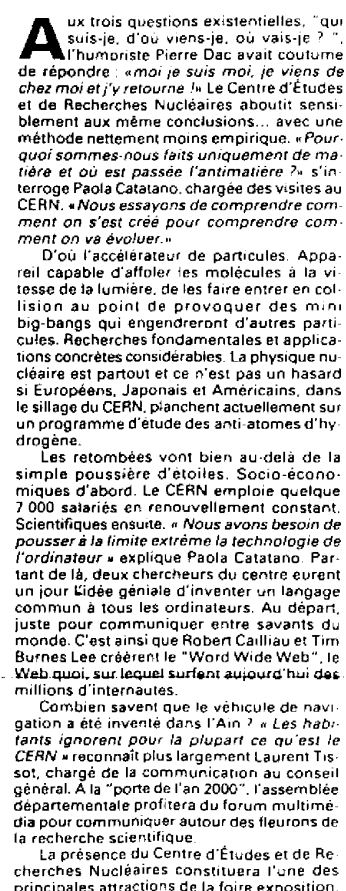

cherches Nucléaires constituera l'une des
principales attractions de la toire exposition.
Si son emploi du temps de voyageur plane.

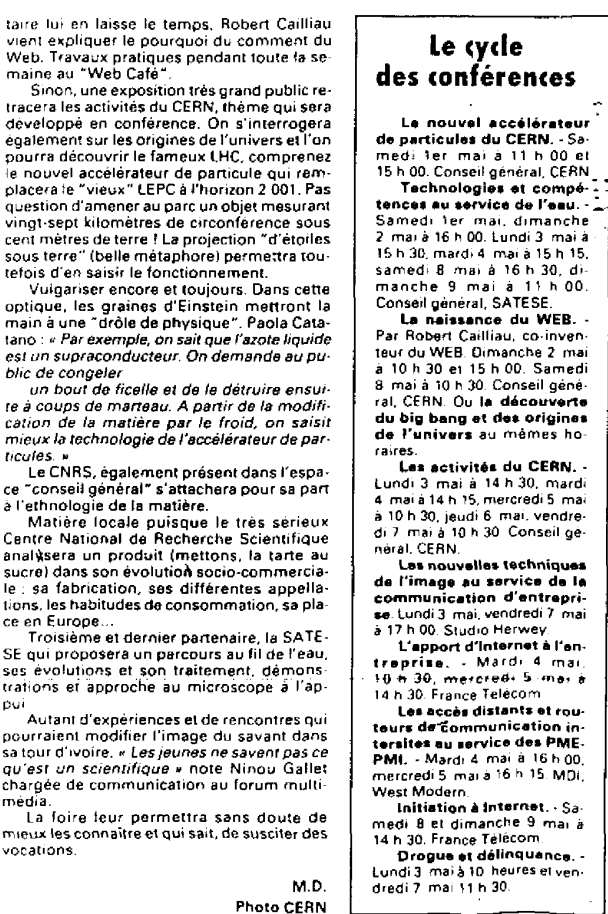

